\title{
Use of Augmented Reality in Learning
}

\author{
György Molnár, Zoltán Szúts, Kinga Biró
}

Budapest University of Technology and Economics (BME)

Müegyetem rkp. 3, 1111 Budapest, Hungary

molnar.gy@eik.bme.hu, szuts.z@eik.bme.hu,biro.kinga@gtdh.bme.hu

\begin{abstract}
Augmented reality offers great solutions in learning because most of high school students are familiar with them. Augmented reality-based applications such as the Pokémon Go 3D, or Quiver and HP Reveal can be used effectively in education. Using AR technology, teachers or even students can create content. For example, triggers using the provided website. The triggers can be image or videos, so the AR experience can be customized. In this study, authors first introduce the augmented reality and a specific application, Pokémon Go, then demonstrate the use of AR in education and finally present a survey conducted among students of a higher education in Hungary.
\end{abstract}

Keywords: ICT; Augmented Reality; higher education; Pokémon GO; HP Reveal

\section{Introduction}

The phenomenon of augmented reality (AR) is primarily relying on usability and entails the analysis of the harmony of sensory organs, linking, tagging, interactivity while the learning process taking place in the respective space [1].

The study explores one principal issue, namely what makes the specific educational applications utilizing augmented reality function?

While augmented reality entails a variety of meanings and presentation forms, common features can be discerned as well. The most important shared attribute is the real time integration of virtual objects into the physical or material world. As a type of mediatized or media-based communication augmented reality is inseparable from the technology making it possible. The respective equipment includes optical devices and other sensors perceiving the external world along with appropriate displays presenting the specific images in high definition. Consequently, via these applications information related to the objective world becomes interactive and digitalized. Thus the given data being stored and made accessible can complement the real world through forming additional informational layers. This also means that augmented reality is device-dependent, technology-determined and convergent at the same time [2] [3] [6]. 
The CogInfoCom focuses on the combination of the natural cognitive capability of humans and ICT. This blending of the natural and artificial cognitive capabilities brings new directions of research, one of them being augmented reality. From CogInfoCom aspects not only the interaction and interfacing between the natural and artificial components is important. In most cases today, it is almost impossible to clearly separate these components, and the authors will not attempt to do so. In their opinion, augmented reality phenomena can be defined as a human-ICT or in other words a blended system, where Inter-cognitive communication: information transfer occurs between two cognitive entities with different cognitive capabilities [18] [19] [20] [21] [22] [23] [24] [25].

\section{Augmented Reality}

\subsection{Augmented Reality (AR)}

The digital revolution gave rise to an incessant need for information and contributed to the decline of traditional information and knowledge accumulation, processing, and transmission structures. It has been indicated earlier that augmented reality can be brought about by a variety of devices and platforms. Consequently, it is related to the phenomenon of media convergence. Augmented reality utilizes three screens or displays, while out of the TV, computer, and mobile telephone trio the phone display has the crucial role. A long time has passed since the first, perhaps less successful attempts of mobile service providers to generate content in a quantity determined by the user. Nowadays content quantity and user activity demands can be reconciled by the adaptation of a proven and tested model to the context of the mobile phone. Thus, users observing the existing operational rules and guidelines must be provided with complete and unlimited access to the worldwide web via a significantly larger and touch operated display screen. As a result of this process the smart phone becomes "the most personal computer".

Since augmented reality based on mobile devices eliminates the need for expensive equipment or the acquisition of new knowledge the number of applications generating additional interactive layers over the physical world is expected to rise [4] [8] [14] [15].

AR uses can be several:

- games

- military use

- medical use 
- entertainment industry

- education

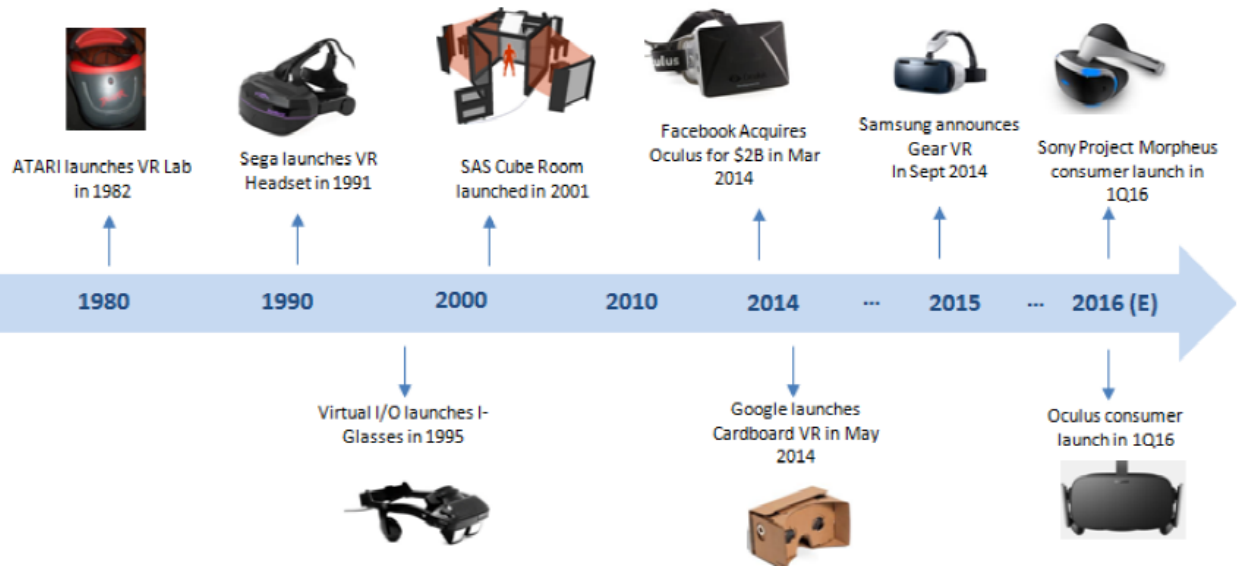

Figure 1

Evolution of AR devices, https://bit.ly/2D8kTWN

Despite the tremendous variety of augmented reality based applications, such programs have shared features as well. All the applications function in real time, and are supported by multimedia and interactivity besides being presented by digital devices. Other common characteristics include being marker based, using community generated content, and requiring proactive user conduct along with interactivity. The real time aspect's primary difference from contents stored in a non-real time manner (picture, video, text) is that it provides the experience of actual presence or participation to the user. The success of participatory media utilizing the activity of the user community underlines the importance of such hands-on experiences.

While its hypertext or hypermedia foundation makes AR similar to the World Wide Web, it is dependent upon different technology. Hypertext is a digitally recorded information carrier containing several links. Its branch structure breaks away from linearity and via hyper references or links provides a range of selection opportunities for the user while calling for interactivity.

AR utilizes an expanded form of hypertext, the hypermedia [1]. The term is used to describe a phenomenon in which the hypertext forms a non-linear unit with still images, motion picture, or music via hyperlinks. Such examples include the online museums, video games, and works relying on augmented reality technologies [7]. 
The technology of AR is marker determined. Marker is as a special identifying code recognized by the sensors igniting the interactive process on the display screen suitable for the given purpose. Augmented reality does not function in the unlimited virtual space, as it operates in a given specific location. Such locations are indicated by markers [11] [12]. Absolute positioned markers refer to a geographic location, while a relative marker emerges in the pictorial symbol recognizable by the system [See Figure 2].

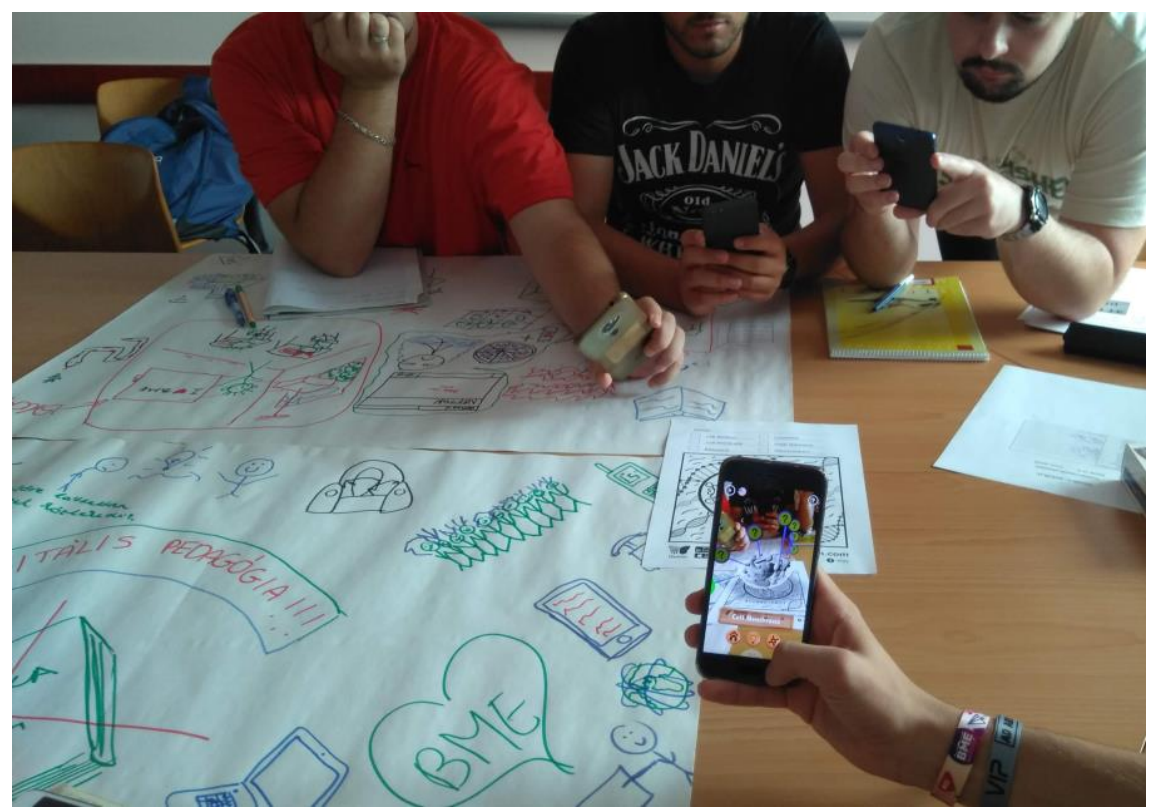

Figure 2

A relative marker used in education

\subsection{Interactivity and Usability}

Interactivity in a multimedia environment refers to a process where a click or touch on a picture or text launches an action leading to another context or starts a video, or displays another text. The continuous evolution of interaction can be accessed in the following manner: Previously, we looked at a picture and mentally traced our own personal cognitive associations to another image. Now the interactive computerized media calls on us to click on a highlighted sentence to reveal another image and follow the pre-programmed objectively present cognitive associations. When new technologies emerge, usability plays a significant role in promoting their integration into the given social and cultural context. The very concept refers to the ease or difficulty of acquiring information needed for problem the appropriate and easy use of the given application. The 
evolution of usability can be represented by a continuum beginning with the mouse and keyboard operated personal computers and ending with touch or motion controlled display screens.

\subsection{The Pokémon Go 3D Application}

Pokémon was an extremely successful video game produced by the Japanese company Nintendo in the middle of the 1990s. The role play game originally designed for a portable Game Boy console reached a sales figure of 155 million in 10 years. The new version launched in 2016 shows no major differences from the original. While it is freely accessible and can be considered a hobby, Nintendo realizes income via purchases generated by the game itself. The game calls for the user to collect and capture the virtual figures by a Poké Ball, then to train them in Gyms and send them into battles or raids against the figures of other players, while building alliances along the Gyms. [See Figure 3]

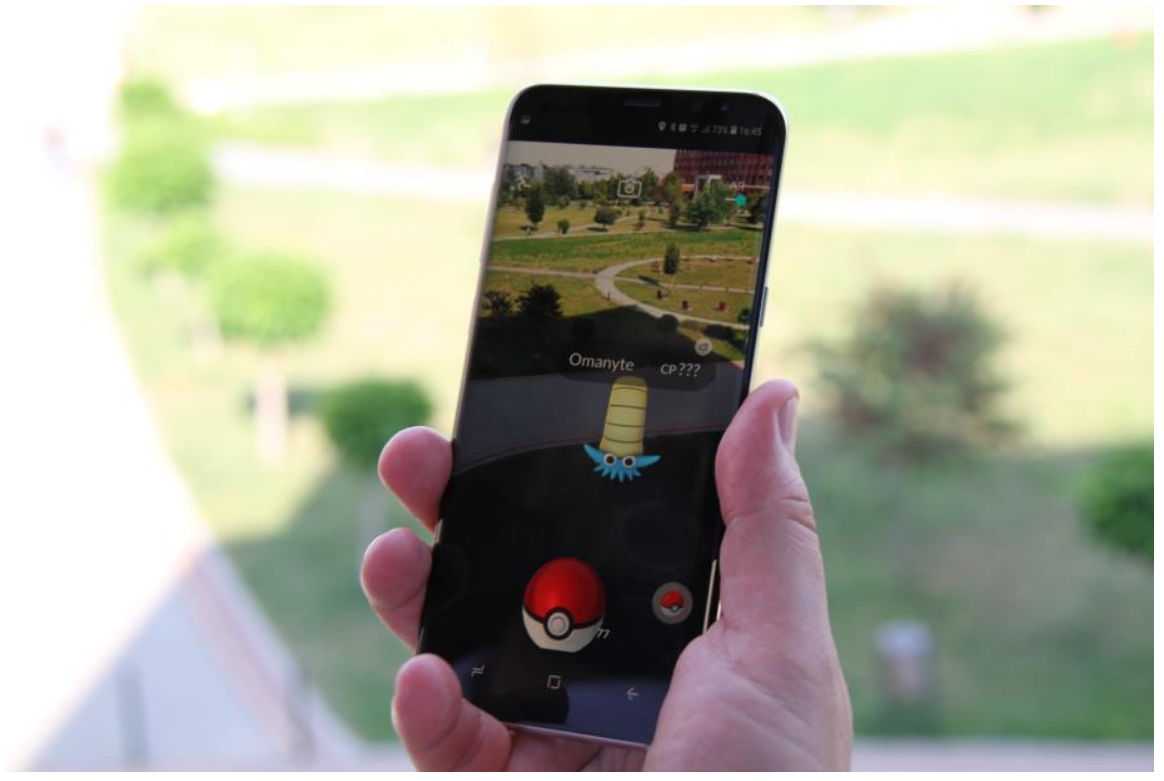

Figure 3

Pokémon Go in action

The success of Pokémon Go is based on the simplification of a complex yet spectacular technology and the promotion or enhancement of the user experience. The enhanced experience includes not only walks in a virtual space, but for example physical discovery of cities and abandoned factories. In addition to a purified and simple surface and easy usability its most important feature is its ability to display pictures embedded in texts thereby enabling the user to enjoy a significantly enhanced participatory experience via multimedia applications. 


\section{Augmented Reality in Education}

Augmented reality can be applied in education. In geography atlases $3 \mathrm{D}$ models can be presented by using mobile devices. This way the scenery comes alive. [See Figure 4] In Biology atlas a human heart may be transformed into a beating, animated virtual organ on the screen. Students are also able to watch experiments in a Physics course. Using smartphones and tablets they can observe experiments from several angles. This way, dangerous or hazardous experiments may be presented safely. However, creating augmented reality content requires a lot of time and skill. Augmented reality can be used in various ways in learning both at formal and non-formal education. If teachers prepare remarkable visual tools, students can consume this content easily and with more motivation. Also, students can create AR elements related to the materials they focus on at the given lesson. When creating their own content, students become more involved in learning, learn how to master the skills and competences on a higher level [31] [32].

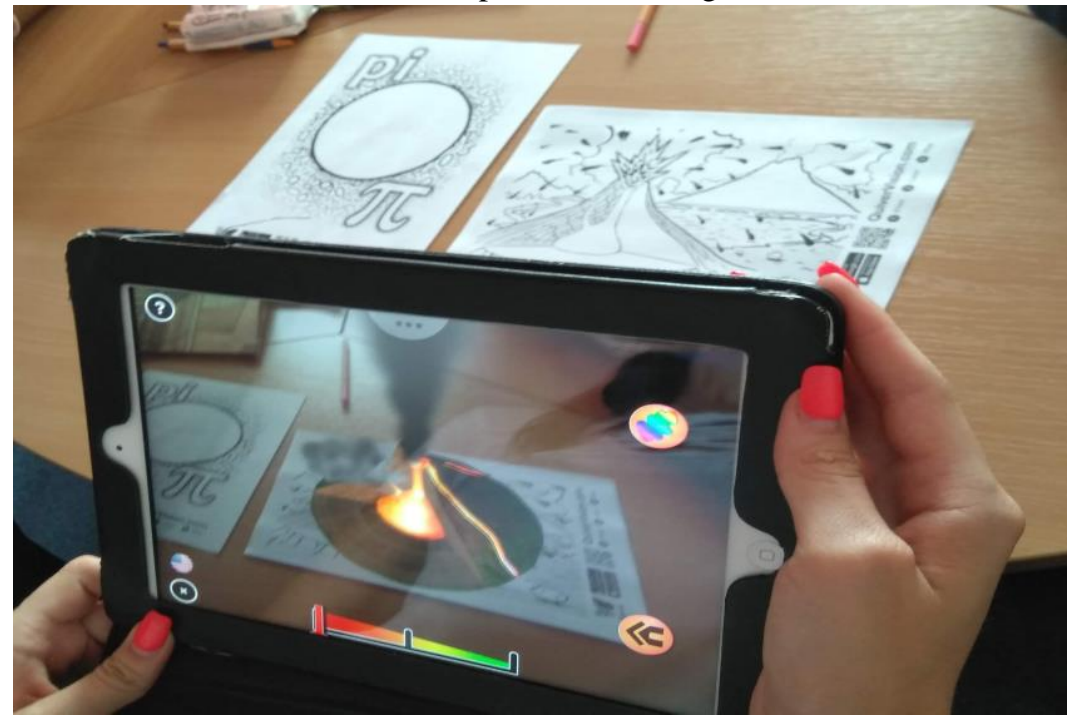

Figure 4

An AR volcano erupting

Apart from the innovative nature of the AR technology and the versatility of its educational use, there is a further advantage. It does not require any particular IT or human resources investment. There is no need for IT specialists to engage in curriculum development, and teachers build lectures based on AR without programming skills, with only general knowledge of IT. As majority of students have smartphones and tablets capable of running AR applications, the BYOD philosophy is applied. All this makes it possible to rapidly spread the AR technology and philosophy in education [8] [9] [13]. 
Augmented reality often improves students learning activity and at the same time enables complex competency-development. As the students often work in a group, it supports project work.

Although the augmented reality is often considered to be a tool of gamification, it is an info communication technology that can create interactive surroundings for the students. The most outstanding ramification of it is a long-lasting experience which can motivate them for further learning and participation in education.

\subsection{Specific AR Platforms and Their Efficiency}

AR apps put students into the story, what makes learning more lively. Instructors can use AR as "distracting" technology to motivate and engage. At the University of Pécs, a 3D visualization in the VR (Virtual Collaboration Arena) learning environment was created in the VirCA platform which suits to the natural cognitive processes of the human brain better [5] [10].

Finally, a good example for VR and AR used in education can be found in several CogInfo papers. According to Horváth: "For accomplishing laboratory practices at a higher level, the 3D VR space also contains video files for facilitating the usage of equipment, instruments and machines at highly-skilled level. These files show the instruments and machines used in the given measurement, the process of making the measurement and the guide for the assessment of the measured data. In this virtual space, the element of the psychologically motivated learning definitions so correct in the every days of the pedagogy was created, according to which learning is not only finding information, but also forming the attitude, as the students learnt in the VR space how to behave during a project. The goal in itself included the "excitement of playing" activated by the creative, innovative attitude [16] [17] [26] [27] [28] [29] [36] [37].

According to Horvath and Sudar, there are some significant and determinate research results on learning efficiency related to AR technology (30\% faster student's activity and team work, $50 \%$ better information comprehension, $50 \%$ more complex information sharing, 30\% less user operations, $80 \%$ less machine operations in the same digital workflow). AR applications play an important role in the field presentation in education. For example, MaxWhere presents the information in 3D environments. Numerous studies have been carried out and published on this issue at the CogInfo conference [30] [33] [34] [35] [38] [39] [40] [41] [42] [43] [44].

There are several AR platforms that can be used in learning. Quiver trigger images when user scan the markers and activates the augmented reality content. The application often uses coloring pages as markers. This also means that younger age groups can be involved into interaction, while motor skills and hand-eye coordination can be improved. It can be used at higher education institutions as well, but there are some limitations. The biggest weakness is the technology itself. 
In theory, 2-3 year old smart devices can run the application. In practice, there are several cases when the devices run out of memory or the internet connection cannot be established.

Similar to Quiver, HP Reveal (former Aurasma) can be used for creating and presenting AR experiences. In this case, teachers or even students can create content. For example, triggers using the provided website. The triggers can be image or videos, so the AR experience can be customized. There are several teachers who insist on creating their own curricula, and HP Reveal can help them accomplish this task.

\section{Empirical Survey}

The primary objective of action research conducted is an empirical inquiry into the digital competence and ICT attitudes of the new generation along with the impact of AR programs and methods on the learning process taking place through student's own devices. The respective survey included a quantitative questionnaire administered to a sample of 91 respondents in the fall of 2017 . The test population assembled via stratified sampling $(\mathrm{N}=91)$ consisted of full-time university students. The eventual and evaluated sample reached a magnitude of 94 . The inquiry based on an interactive, Kahoot measurement device, enabling the user to have a hands-on experience utilized the BYOD method as well. The target group primarily consisted of university students enrolled in engineering programs and representing the generations $\mathrm{Y}$ and $\mathrm{Z}$. The survey mostly utilized close ended questions and the results were processed via simple descriptive statistical methods and presented in diagrams. The graphs below show only the processed data related to AR use.

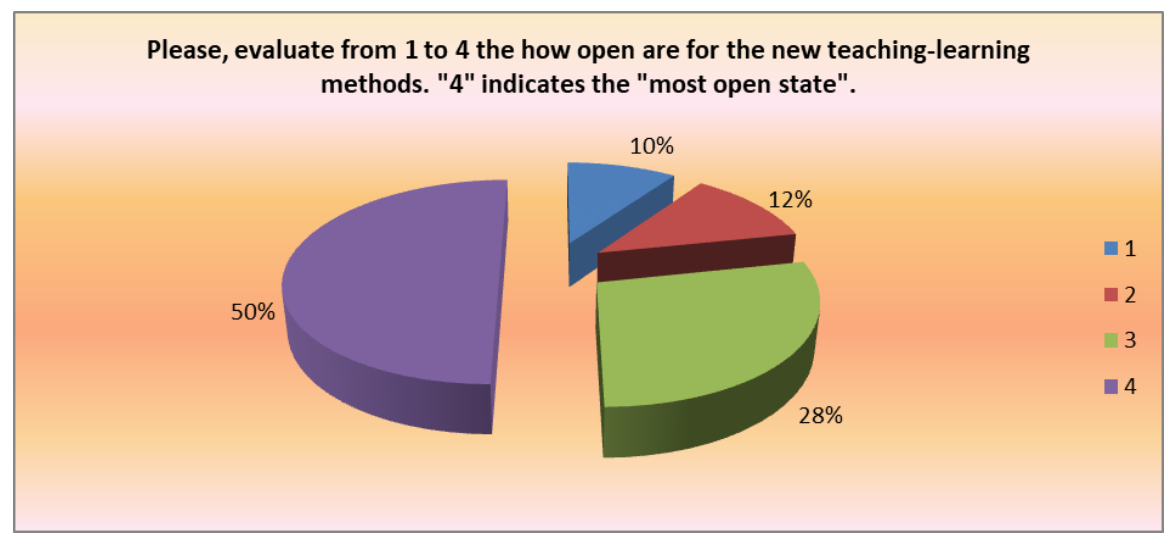

Figure 5

How open are the students for new teaching-learning methods 
Figure 5 displays the level of respondents' acceptance of modern, new type, and open teaching and learning methods. The respective results indicated that $50 \%$ of the respondents is fully open to new instruction and learning methods, while about one quarter (28\%) is rather receptive (3), and only $12 \%$ (2) and 10\% (1) indicated their reluctance to integrate the new generation teaching methods into their learning efforts.

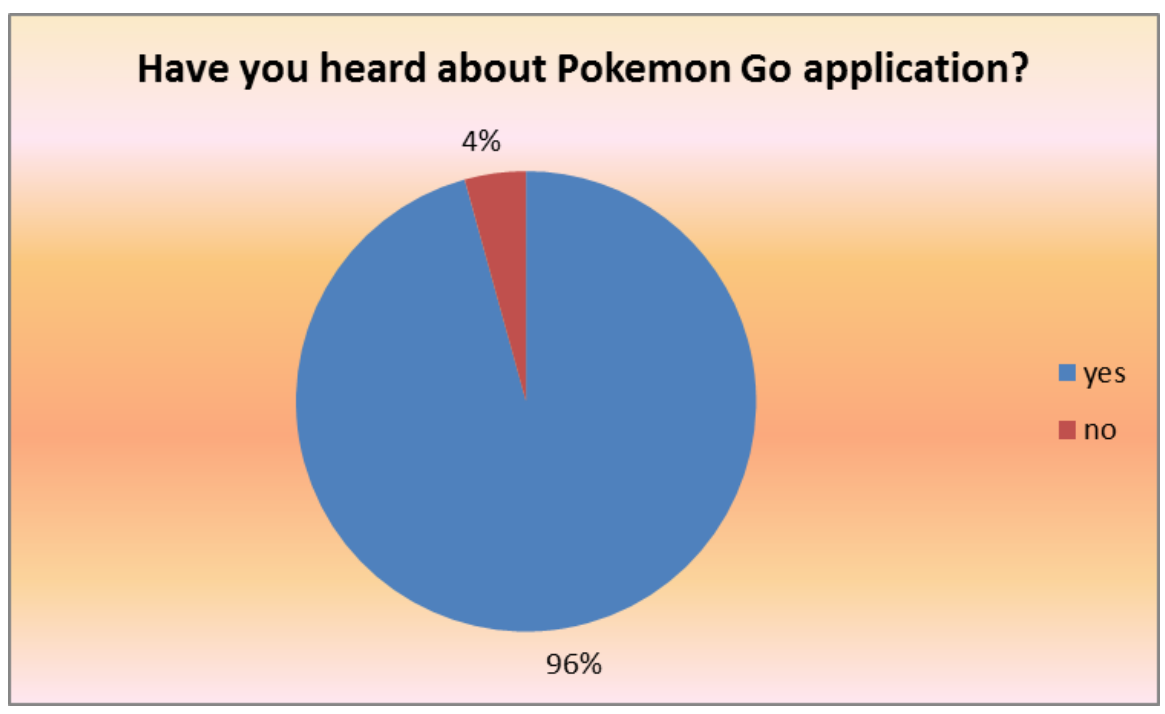

Figure 6

Popularity of Pokémon Go application

96\% of the respondents have heard about the Pokémon Go application, and its popularity is indicated by the fact that most of them tried it as well.

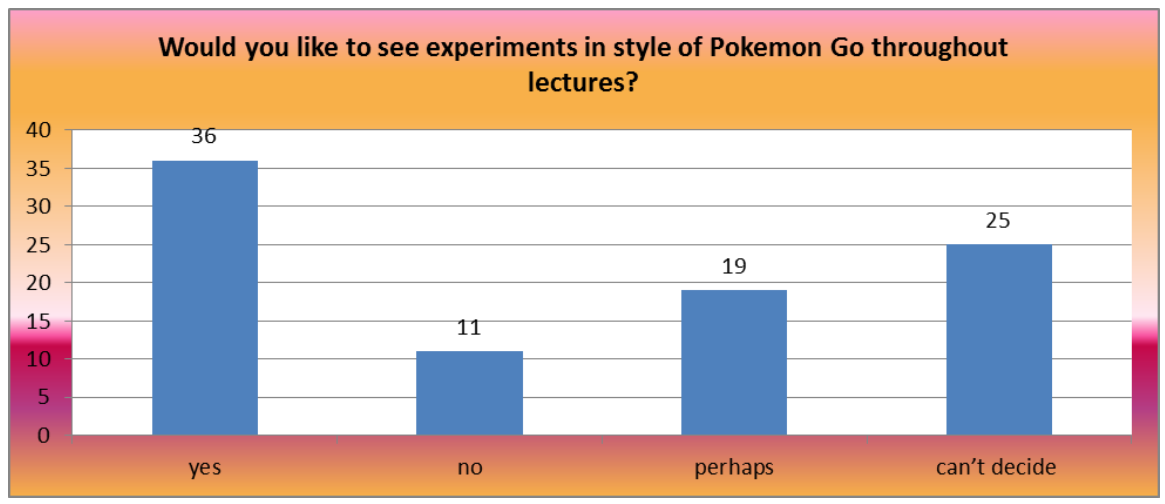

Figure 7

Acceptance of AR use in lectures 
Figure 7 partly substantiates the answers given to Question 4. The question probed the extent, to which augmented reality-based applications such as Pokémon Go is liked by students, More than one third of the respondents, 22 people would like to listen to lectures via such interactive virtual reality context, 12 respondents could not assess the significance or importance of the given question, and only 8 out of 70 respondents stated that they would not like to participate in lectures or learning experiments utilising virtual reality, Furthermore 17 respondents indicated openness toward participating in such new type learning experiments.

\section{Conclusions}

The appreciation of visuality is assisted by the virtual and augmented reality spaces. The cyberspace that houses these offers a promising and beneficial way of life to the digital citizens in both public life and learning, given the fact that these citizens attend the courses only when they wish or have the time for those. Obviously, in order to be successful in it, they must use the digital devices constantly and must acquire the self-driven and informal learning.

\section{References}

[1] Azuma, R., A Survey of Augmented Reality. Hughes Research Laboratories, Malibu, 1997

[2] P. Baranyi, A. Csapo and Gy. Sallai, Cognitive Infocommunications (CogInfoCom). Springer, 2015

[3] P. Baranyi, A. Csapó, "Definition and Synergies of Cognitive Infocommunications," Acta Polytechnica Hungarica, Vol. 9, No. 1, pp. 6783,2012

[4] I. Horváth, "Innovative Engineering Education in the Cooperative VR Environment," $20167^{\text {th }}$ IEEE International Conference on Cognitive Infocommunications (CogInfoCom), Wroclaw, 2016, pp. 000359-000364 DOI: 10.1109/CogInfoCom.2016.7804576

[5] Dr. Schuster, G., \& Terpecz, G, "A virtuális tanulási környezetek (VTK) alkalmazása a mérnök-müszaki oktatásban,” Repüléstudományi közlemények, 24. évf. 2. sz., 295-306, 2012

[6] L. Manovich, The Language of New Media, MIT Press, 2001

[7] R. C. Chang and Z. S. Yu, "Application of Augmented Reality technology to promote interactive learning," 2017 International Conference on Applied System Innovation (ICASI), Sapporo, Japan, 2017, pp. 1673-1674. DOI: 10.1109/ICASI.2017.7988257

[8] Z, Szüts, \& Y. Jinil, A kiterjesztett valóság térhódítása. Információs Társadalom, Vol. 13, No. 2, 2013, pp. 58-67 
[9] T. Matuszka, Kiterjesztett valóság alkalmazások ejlesztése, elemzése és a fejlesztőeszközök összehasonlítása. ELTE, Informatikai Kar, Média- és Oktatásinformatika Tanszék, 2012

[10] Veteknoloji, Pokémon GO'ya Güncelleme Geldi [Online]. Available: http://www.veteknoloji.net/haber/pokemon-go-ya-guncelleme-geldi84328.html [Accessed: 01- Jun- 2017]

[11] Gy. Molnár, The Role of Electronic and Virtual Learning Support Systems in the Learning Process, In: Szakál Anikó (ed.) IEEE $8^{\text {th }}$ International Symposium on Applied Computational Intelligence and Informatics: SACI 2013, New York: IEEE, 2013, pp. 51-54

[12] Gy. Molnár, Z. Szüts, Visual Learning - Picture and Memory in Virtual Worlds, In: András Benedek, Kristóf Nyíri (ed.) Beyond Words: Pictures, Parables, Paradoxes. Frankfurt: Peter Lang Verlag, 2015. pp. 153-161

[13] A. Abonyi-Tóth, A mobiltechnológiával támogatott tanulás és tanítás módszerei. Educatio Társadalmi Szolgáltató Nonprofit Kft. Digitális Pedagógiai Osztály, IKT Módszertani Iroda, 2015

[14] L. Sikné, A virtuális valóság és alkalmazásai. Egyetemi jegyzet. Veszprém, Pannon University, 2003

[15] A. Benedek, Digitális pedagógia, mobil tanulás és új tudás, Szakképzési Szemle, Vol. 23, No. 1, 2007, pp. 7-19

[16] J. Katona, T. Ujbanyi, A. Kovari, "Investigation of the Correspondence between Problems Solving Based on Cognitive Psychology Tests and Programming Course Results," in International Journal of Emerging Technologies in Learning, Vol. 10, No. 3, 2015. pp. 62-65, DOI: 10.3991/ijet.v10i3.4511

[17] P. Dukan and A. Kovari, "Cloud-based Smart Metering System," 2013 IEEE $14^{\text {th }}$ International Symposium on Computational Intelligence and Informatics (CINTI) Budapest, 2013, pp. 499-502, DOI: 10.1109/CINTI.2013.6705248

[18] A. Kovari and P. Dukan, "KVM \& OpenVZ Virtualization-based IaaS Open Source Cloud Virtualization Platforms: OpenNode, Proxmox VE," 2012 IEEE $10^{\text {th }}$ Jubilee International Symposium on Intelligent Systems and Informatics, Subotica, 2012, pp. 335-339, DOI: 10.1109/SISY.2012.6339540

[19] I. Farkas, P. Dukan, J. Katona and A. Kovari, "Wireless Sensor Network Protocol Developed for Microcontroller-based Wireless Sensor Units, and Data processing with Visualization by LabVIEW," 2014 IEEE $12^{\text {th }}$ International Symposium on Applied Machine Intelligence and Informatics (SAMI) Herl'any, 2014, pp. 95-98, DOI: 10.1109/SAMI.2014.6822383 
[20] J. Katona and A. Kovari, "A Brain-Computer Interface Project Applied in Computer Engineering," in IEEE Transactions on Education, Vol. 59, No. 4, pp. 319-326, Nov. 2016, DOI: 10.1109/TE.2016.2558163

[21] J. Katona, A. Kovari, "EEG-based Computer Control Interface for BrainMachine Interaction," in International Journal of Online Engineering, Vol. 11, No. 6, pp. 43-48, 2015

[22] J. Katona, T. Ujbanyi, G. Sziladi and A. Kovari, "Speed Control of Festo Robotino Mobile Robot Using NeuroSky MindWave EEG Headset-based Brain-Computer Interface," $20167^{\text {th }}$ IEEE International Conference on Cognitive Infocommunications (CogInfoCom) Wroclaw, 2016, pp. 000251000256, DOI: 10.1109/CogInfoCom.2016.7804557

[23] K. Biró, A korszerü mobil IKT eszközökkel támogatott, virtuális és augmentált tanulási környezetek a pedagógiai gyakorlatban, In: Éva Borsos, Zsolt Námesztovszki, Ferenc Németh (ed.) A Magyar Tannyelvü Tanítóképző Kar 2017-es tudományos konferenciáinak tanulmánygyüjteménye [Zbornik Radova Nachnih Konferencija Uchitel'skov Fakulteta na Magarskom Nastavnom Jeziku 2017]: Tanulmánygyüjtemény [Zbornik radova] [Book of selected papers] Szabadka: Újvidéki Egyetem Magyar Tannyelvű Tanítóképző Kar, 2017. pp. $835-848$

[24] T. Ujbanyi, J. Katona, G. Sziladi and A. Kovari, "Eye-Tracking Analysis of Computer Networks Exam Question Besides Different Skilled Groups," $20167^{\text {th }}$ IEEE International Conference on Cognitive Infocommunications (CogInfoCom), Wroclaw, 2016, pp. 000277-000282, DOI: 10.1109/CogInfoCom.2016.7804561

[25] Námesztovszki Zsolt - Glušac Dragana - Branka Arsović, A tanulók motiváltsági szintje egy hagyományos és egy IKT eszközökkel gazdagított oktatási környezetben, OKTATÁS-INFORMATIKA 2013: pp. 2061-1870

[26] I. Horvath, A. Sudar: "Factors Contributing to the Enhanced Performance of the MaxWhere 3D VR Platform in the Distribution of Digital Information" Acta Polytechnica Hungarica, in print

[27] I. Horváth: "The IT Device Demand of Edu-Coaching in the Higher Education of Engineering", $8^{\text {th }}$ IEEE International Conference on Cognitive Infocommunications, Debrecen, 2017

[28] Z. Kvasznicza: "Teaching Electrical Machines in a 3D Virtual Space", $8^{\text {th }}$ IEEE International Conference on Cognitive Infocommunications, Debrecen, 2017

[29] A. Lloyd, S. Rogerson, G. Stead: "Imagining the Potential for Using Virtual Reality Technologies in Language Learning” In: Michael Carrier, Ryan M. Damerow, Kathleen M. Bailey (eds.) Digital Language Learning and Teaching: Research, Theory, and Practice, New York, Taylor \& Francis, 2017 
[30] I. Horváth, "Innovative Engineering Education in the Cooperative VR Environment," $20167^{\text {th }}$ IEEE International Conference on Cognitive Infocommunications (CogInfoCom), Wroclaw, 2016, pp. 000359-000364, DOI: 10.1109/CogInfoCom.2016.7804576

[31] Hercegfi K, Event-related Assessment of Hypermedia-Based E-Learning Materials With an HRV-based Method That Considers Individual Differences in Users, International Journal of Occupational Safety and Ergonomics 17:(2) 2011, pp. 119-127

[32] Komlódi A, Hercegfi K, Józsa E, Köles M, Human-Information Interaction in 3D Immersive Virtual Environments, In: IEEE (ed.) Cognitive Infocommunications (CogInfoCom): $3^{\text {rd }}$ IEEE International Conference on Cognitive Infocommunications. Piscataway (NJ): IEEE, 2012, pp. 597-600

[33] B. Szenkovits, J. Horváth Czinger, Gy. Molnár, K. Nagy, Z. Szüts, Gamification and Microcontent-orientated Methodological Solutions Based on Bring-Your-Own Device Logic in Higher Education, In: Sallai Gyula (ed.) $9^{\text {th }}$ IEEE International Conference on Cognitive Infocommunications: CogInfoCom 2018 Proceedings. Piscataway (NJ): IEEE Computational Intelligence Society, 2018, pp. 385-388

[34] Gy. Molnár, D. Sik, Supporting Learning Process Effectiveness with Online Web 2.0 Systems on the basis of BME Teacher Training, In: Sallai Gyula (ed.) $9^{\text {th }}$ IEEE International Conference on Cognitive Infocommunications: CogInfoCom 2018 Proceedings. Piscataway (NJ): IEEE Computational Intelligence Society, 2018, pp. 337-340

[35] E. Gogh, A. Kovari, Metacognition and Lifelong Learning: A Survey of Secondary School Students, In: Sallai Gyula (ed.) $9^{\text {th }}$ IEEE International Conference on Cognitive Infocommunications: CogInfoCom 2018 Proceedings. Piscataway (NJ): IEEE Computational Intelligence Society, 2018, pp. 271-276

[36] B. Lampert, A. Pongracz, J. Sipos, A. Vehrer, I. Horvath "MaxWhere VRLearning Improves Effectiveness over Clasiccal Tools of e-learning", Joint Special Issue on TP Model Transformation and Cognitive Infocommunications, in Acta Polytechnica Hungarica, 2018, DOI: 10.12700/APH.15.3.2018.3.8

[37] I. Horvath, A. Sudar, "Factors Contributing to the Enhanced Performance of the MaxWhere 3D VR Platform in the Distribution of Digital Information", Joint Special Issue on TP Model Transformation and Cognitive Infocommunications, in Acta Polytechnica Hungarica, 2018, DOI: 10.12700/APH.15.3.2018.3.9

[38] B. Berki "2D Advertising in 3D Virtual Spaces", Joint Special Issue on TP Model Transformation and Cognitive Infocommunications, in Acta Polytechnica Hungarica, 2018, DOI: 10.12700/APH.15.3.2018.3.10 
[39] T. Budai, M. Kuczmann, Joint Special Issue on TP Model Transformation and Cognitive Infocommunications, in Acta Polytechnica Hungarica, 2018, DOI: 10.12700/APH.15.3.2018.3.11

[40] V. Kövecses-Gösi, "Cooperative Learning in VR Environment", Joint Special Issue on TP Model Transformation and Cognitive Infocommunications, in Acta Polytechnica Hungarica, 2018, DOI: 10.12700/APH.15.3.2018.3.12

[41] I. Horváth, The Edu-Coaching Method in the Service of Efficient Teaching of Disruptive Technologies, Cognitive Infocommunications, Theory and Applications, pp. 349-363, Springer, Part of the Topics in Intelligent Engineering and Informatics book series (TIEI, Vol. 13) https://link.springer.com/chapter/10.1007/978-3-319-95996-2_16. 2018

[42] I. Horváth, Evolution of Teaching Roles and Tasks in VR / AR-based Education, CogInfoCom 2018 Conference, Budapest, Hungary 22-24, 08.2018

[43] Á. Csapó, I. Horváth, P. Galambos, P. Baranyi, VR as a Medium of Communication: from Memory Palaces to Comprehensive Memory Management, CogInfoCom 2018 Conference, Budapest, Hungary 22-24, 08.2018

[44] P. Bőczén-Rumbach, "Industry-oriented Enhancement of Information Management Systems at AUDI Hungaria using MaxWhere's 3D Digital Environments" $20189^{\text {th }}$ IEEE International Conference on Cognitive Infocommunications (CogInfoCom) Budapest, 2018, pp. 417-422 